\title{
EDUCATION, CHANGE OF CONSUMER PREFERENCES AND GROWTH
}

\author{
Renato Balducci ${ }^{1}$
}

\begin{abstract}
The paper examines the effects on growth of both private and public investment in health, schooling and culture: in short, education. These expenditures exert two effects on the growth rate: (i)they increase labour and capital stock productivity through a positive externality, and (ii) they modify saving and investment decisions through the substitutability between education and private consumption. The different effects on economic growth of publicly financed education and private investment in education are investigated. The optimal growth rate depends on households' preferences for education. Moreover, there will be always an optimal tax rate that produces the same rate of growth in alternative regimes, private and public, of education financing. Universalistic public education exerts a strong positive externality on the economic efficiency but unlike private investments - it does not create sufficient incentives through income differentials to change consumer preferences for education.
\end{abstract}

\section{JEL:H5-O4}

Key words: education, private and public regimes, growth

\footnotetext{
${ }^{1}$ Professore Ordinario di Economia Politica

Università Politecnica delle Marche - Dipartimento di Economia

P.le Martelli, 8 - 60121 Ancona (Italy)

e-mail: balducci@dea.unian.it
}

I thank ....... and all participants at the workshop on Economic Growth:Institutional and Social Dynamics, Pisa,....., financed by PRIN 2005, for their useful comments. All remaining errors and opinions are entirely my responsibility. 


\section{Introduction}

The idea that investment in education, both public and private, can promote economic growth was recognized by New Growth Theory ${ }^{2}$, contrary to the neoclassical theory that preceded it. $^{3}$ Lucas (1988) argued that investment in (that is, time dedicated to) schooling increases the stock of human capital and the long run rate of growth. Similarly, government spending on research and development (Romer, 1990), on schooling (Becker (1993), Glomm and Ravikumar (1992), Mincer (1974), Willis and Rosen (1979), Willis (1986)), on health (Barro (1996), Bloom et al, (2001), de la Croix and Doepke (2004), Galor and Mayer (2002), Hosoya (2003), Howitt (2002), Van Zon and Muyshen (2001)), and on public infrastructures fosters economic development, introducing an externality into private decisions on production. In particular, education has a positive effect on labour productivity (Bloom et al. (2001)), improving creativity, learning capacity and copying skills (Howitt, (2002). ${ }^{4}$

A different approach derives from Barro $(1990)^{5}$. The basic hypothesis of this model is that the government provides free public services to firms, such as defence of property rights, spending on justice, health, education, and so on. Public spending, financed with proportional taxes on income, affects the production function, which is with constant returns to scale in two production factors: physical capital stock and public investment. ${ }^{6}$ On maximising the utility of private consumption, one obtains a constant steady-state growth rate which is influenced by public spending on education. An increase in the tax rate and in public investment in education fosters economic growth up to a threshold ${ }^{7}$; beyond this value the growth rate decreases.

An extension of this important result has been advanced by Barro (1990) himself: "We could also allow for public consumption services as an influence on households' utility”. However, public

\footnotetext{
*Department of Economics, Polytechnical University of Marche, P.le Martelli,8, 60121 Ancona (e-mail: balducci@dea.unian.it).

I am indebted to .....for their useful comments and suggestions. All remaining errors and omissions are entirely my responsibility.

${ }^{2}$ The authors and studies that have given rise to New Growth Theory are the following: Romer (1986), (1990), (1994); Lucas (1988); Barro (1990); Barro and Sala-I-Martin (1992),(1995), Jones and Manueli (1990), S. T. Rebelo (1991); P. Aghion and P. Howit (1992), Alesina and Rodrik (1994).

${ }^{3}$ As regards neoclassical growth theory, reference is made principally to Robert Solow's (1956) model. On the economic policy implications of new growth theory see the following works: M. F. Scott (1992); K. G. Shaw (1992), Bajo-Rubio (2000).

${ }^{4}$ For an interesting survey of the literature on fiscal policy and economic growth, see Zagler and Durneker (2003). In a recent paper, Peretto (2003) shows that in a model of endogenous growth that does not exhibit the scale effect, the level and composition of public expenditure have no effect on steady-state growth, but only on per capita income. See also Futagami, Morita and Akihisa (1993), Greiner and Hanush (1998), Bajo-Rubio (2000), Turnovsky (1996, 2000). ${ }^{5}$ R. J. Barro (1990), op. cit. See also Barro and Sala-I-Martin (1992), (1995) . Public investments are non rival and non excludable, like public goods.

${ }^{6}$ That is, an 'AK' production function as defined by S. T. Rebelo (1991), op. cit.

7 See Barro (1990), op.cit., p. 109.
} 
consumption slows economic growth because it reduces private income net of taxes without increasing the productivity of the capital stock.

In this paper I examine the effect on the growth rate of both private and public investment in health, schooling and culture: in short, education. Investment in education exerts two effects on the economic growth: (i) it increases the productivity of the capital stock, and (ii) it modifies the households saving decisions through the substitutability (Flessig and Rossana, (2003)) between education and consumption. I do not follow Lucas's (1988) approach, according to which the engine of (or the binding constraint on) the economic growth is the time share dedicated to the accumulation of human capital. In my opinion the effective binding constraint for growth are the financial resources available to invest in schooling. This financial constraint could be relaxed only if perfect capital markets were willing to finance private investment in schooling. In reality this does not happen. Financial resources bind a person's possibility of continuing his or her studies. For this reason, I consider as most interesting the methodological approach taken by Barro's (1990) model, according to which public spending on schooling produces externalities to firms which support economic growth.

In this paper I analyze whether the public or private financing of education are equivalent in relation to long run economic growth. In general the answer is 'no'. Public financing of education for the entire school-age population exerts an important positive externality on the productivity of labour and gives rise to a positive steady-state rate of growth. However, universalistic public education provision does not produce income differentials sufficient to modify private preferences in favour of education. Otherwise, in the case of private financing of education, there will be a share of individuals who first achieve a higher level of education and obtain higher per capita income (see: Griliches (1977), Erickson and Ichino (1992), Lucifora (1994), Psacharopoulos (1994), Benabou (1994), Card (1995), Harmon and Walzer (1995), Galor and Tsidon (1997), Epple and Romano (1998), Ichino and Winter-Ebmer (1998), Manacorda (2000), Miguel (2005), Sala-I-Martin (2005)). Their preferences shift towards higher levels of education, and this in turn generates further investment in education and higher earnings. However, this cumulative process encounters a limit: the greater the share of the higher educated population, the more rapidly education becomes an externality, exactly as happens with universalistic public schooling.

Section 2 presents a model of endogenous growth like Barro's (1990) model in which the engine of economic growth is private investment in education. Section 3 extends this model to the case of the public financing of education and compares the two optimal rates of growth. Section 4 describes the evolution of individuals' preferences engendered by investment in education and 
illustrates the differences between the private and public financing of education. Section 5 concludes.

\section{A model of growth with private investment in education.}

I shall construct a simple model of endogenous growth with expenditure on education $h(t)^{8}$ in the utility function and in the production function.

The production function, in terms of constant labour units, ${ }^{9}$ is a Cobb-Douglas with constant returns to scale in physical capital stock $\mathrm{k}(\mathrm{t})$ and investment in education $\mathrm{h}(\mathrm{t})$ :

$1 \quad y(t)=k(t)^{\alpha} h(t)^{1-\alpha}$

$$
y_{k}(t)=\alpha x(t)^{1-\alpha}, \quad y_{h}(t)=(1-\alpha) x(t)^{-\alpha}
$$

where: $x(t)=\frac{h(t)}{k(t)}$

The disposable income of a representative household is spent on consumption and investment in physical capital and in education:

2

$$
y(t)=c(t)+k(t)+h(t)
$$

The utility function is hypothesised as being of CRRA type, its arguments being consumption $c(t)$, with weight $(1-\beta)$, and education $h(t)$, with weight $0 \leq \beta<1$ :

$3 u(t)=\frac{\left[c(t)^{1-\beta}\left(\not h(t)^{\beta}\right]^{1-\sigma}\right.}{1-\sigma} \quad u_{c}(t)=(1-\beta)(1-\sigma) \frac{u(t)}{c(t)}, \quad u_{h}(t)=\beta(1-\sigma) \frac{u(t)}{h(t)}$

where $\gamma$ indicates the value in terms of the utility of the investment in education.

The household maximises the current value of future flows of utility, choosing both consumption $c(t)$ and investment in education $h(t)$ in respect of the dynamic constraint (2), given a positive initial capital stock: $k(0)=k_{0}>0$. In appendix A this optimal control problem is solved and the steady state growth rate is obtained as the solution of the following implicit equation:

\footnotetext{
${ }^{8}$ Note that $\mathrm{h}(\mathrm{t})$ is the annual flow of investment in schooling, and not the stock of human capital as in Lucas (1988).

${ }^{9}$ For simplicity, the units of population at the initial date are normalised to $1, N(t)=1$, and the rate of growth of the population is assumed to be nil: $\mathrm{n}=0$.
} 
(4) $\quad Z(g)=[B(\beta)-\beta] g-\left(\frac{\sigma g+\rho}{\alpha}\right)^{\frac{1}{1-\alpha}}+B(\beta) \rho=0$

where: $B(\beta)=\sigma\left[\frac{1-\alpha}{\alpha}+\beta\right]$

Note that if: $\beta<\frac{\sigma(1-\alpha)}{(1-\sigma) \alpha}$, or if : $\sigma \geq \alpha$ (sufficient conditions), the term in the square brackets: $B(\beta)-\beta$ is always positive. I assume that at least one of these conditions is always satisfied. It is then easy to ascertain that $\mathrm{Z}(\mathrm{g})$ is a concave function of $\mathrm{g}$ increasing up to $\mathrm{g}_{\min }$ and thereafter decreasing:

$$
\frac{\partial Z(g)}{\partial g}=[B(\beta)-\beta]-\frac{\sigma}{\alpha(1-\alpha)}\left(\frac{\sigma g+\rho}{\alpha}\right)^{\frac{\alpha}{1-\alpha}}<0 \quad \text { for } g>\mathrm{g}_{\min } 10
$$

It is interesting to study the relation between the value $\mathrm{g}^{*}$ such that $\mathrm{Z}\left(\mathrm{g}^{*}\right)=0$ and the preference for education $\beta$ :

$$
\frac{\partial g^{*}}{\partial \beta}=\frac{(1-\sigma) g^{*}-\rho}{(\partial Z(g) / \partial g)}>0 \quad \text { if } \quad g_{\min }<g^{*}<\frac{\rho}{1-\sigma}
$$

Therefore, if households consider $h(t)$ to be useful, i.e. $\beta>0$, the steady state rate of growth increases with $\beta$ (see figure 1).

When $\beta=0$, the value of $\mathrm{x}^{*}(\beta=0)$ (see appendix $A$ ) is minimum and the rate of growth is lowest:

$$
g *(\beta=0)=\frac{1}{\sigma}\left[\alpha(1-\alpha)^{\frac{1-\alpha}{\alpha}}-\rho\right]
$$

In general, the following proposition holds:

\footnotetext{
${ }^{10}$ Note that $g_{\min }$ is the value of $g$ such that $\frac{\partial Z(g)}{\partial g}=0$.
} 
Proposition 1: When the optimal investment in education is privately decided and financed, the steady state rate of growth is an increasing function of households' preferences for education through the optimal ratio between investment in education and in physical capital: $g^{*}=g\left[x^{*}(\beta)\right]$.

Figure 1: Steady state rate of growth $g *$ in function of the preferences for education. Values of the parameters: $\alpha=0.3, \sigma=0.75, \rho=0.05$

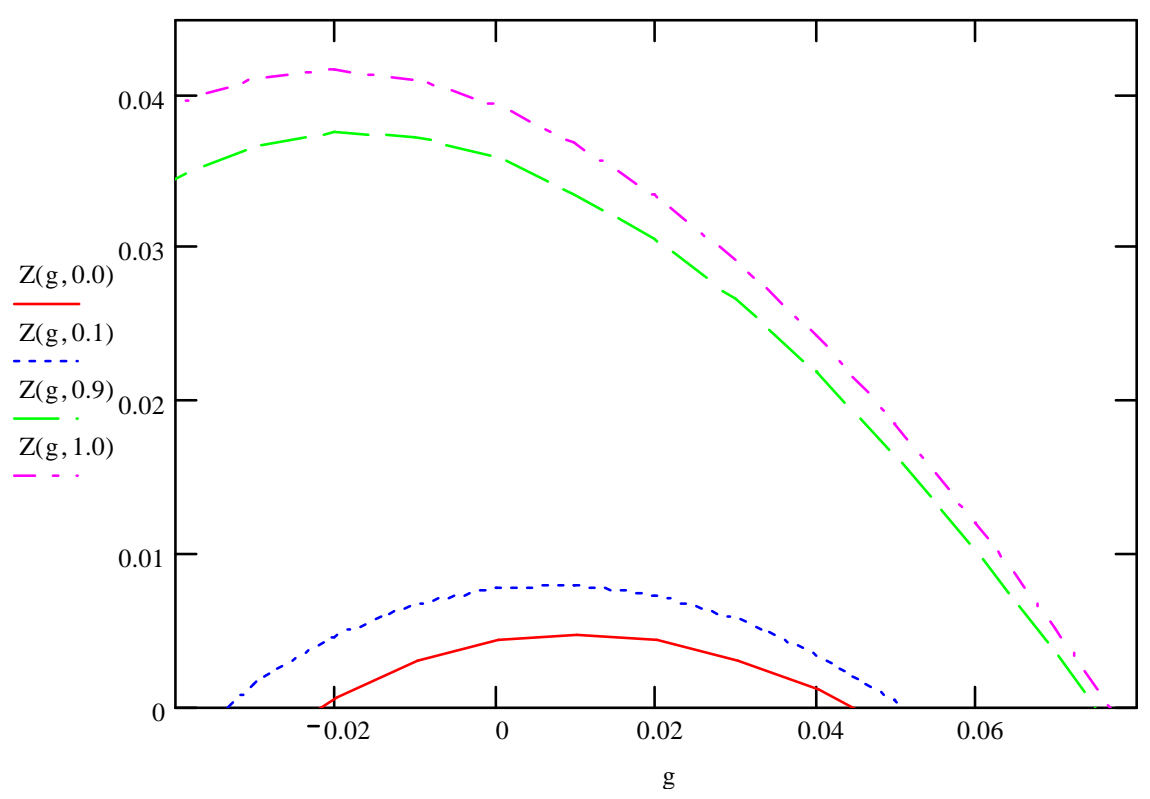

The steady state utility of a representative household, taking into account the optimal constant ratio between education and consumption $(\gamma \mathrm{h} / \mathrm{c})^{*}$, is the following:

$$
u[c(t), h(t)]=\left[\frac{\left(\not h * / c^{*}\right)^{\beta} c_{0} e^{g(\beta) t}}{1-\sigma}\right]^{1-\sigma}
$$

The effect of a change in households' preferences for education is the sum of two components: (i) change in the optimal ratio between education and consumption $(\gamma \mathrm{h} / \mathrm{c})^{*}$, and (ii) change in optimal consumption, which grows at the rate $g(\beta)$ :

$$
\frac{\partial u(.)}{\partial \beta}=(1-\sigma) u\left(c^{*}, h^{*}\right)\left[\ln (\not h / c) *+\ln c_{0}+t \frac{\partial g(\beta)}{\partial \beta}\right]
$$


Thus, in the long run, a shift of households' preferences to education increases utility, given that the effect of $\beta$ on the rate of growth is positive.

\section{$3 \quad$ Public investment in education and growth.}

3.1 Now consider the same previous framework assuming that the government imposes a proportional income tax rate, $0<\tau<1$ to finance public investments in education $h(t)=\tau y(t)$. The government is a benevolent planner which maximizes the household utility function by choosing the optimal income tax rate $\tau^{*}$. The household utility function is hypothesised as being of CRRA type, as in Section 2. ${ }^{11}$

The production function, in terms of constant labour units, with $\mathrm{N}(\mathrm{t})=1$, is the same CobbDouglas function as introduced in equation (1). If economic agents know the public budget constraint: $h(t)=\tau(t)$, the production function can be written as follows:

$$
y(t)=k(t)^{\alpha} h(t)^{1-\alpha}=k(t)^{\alpha}(\tau y(t))^{1-\alpha}=A(\tau) k(t)
$$

where : $A(\tau)=\tau^{\frac{1-\alpha}{\alpha}} \quad, A_{\tau}=A(\tau) \frac{1-\alpha}{\alpha \tau}$

Given that education is freely provided by the public sector, the disposable income of a representative household is spent on private consumption and physical investment only:

$$
(1-\tau) A(\tau) k(t)=c(t)+\dot{k}(t)
$$

In appendix $B$ this optimal control problem is solved and the steady state growth rate is obtained as the solution of the following implicit equation:

$$
Z(g)=[B(\beta)-\beta] g-\left(\frac{\sigma g+\rho}{\alpha}\right)^{\frac{1}{1-\alpha}}+B(\beta) \rho=0
$$

\footnotetext{
${ }^{11}$ The derivative of $\mathrm{u}(\mathrm{t})$ with respect to $\tau$ is : $u_{\tau}(t)=\frac{\beta(1-\sigma)}{\alpha \tau} u($.
} 
Note that the solution of the government's optimum control problem, equation (8), is identical to equation (4) obtained as the solution of the households' optimum control problem. Therefore the steady state rate of growth is the same in the case of both public and private financing of schooling.

When households do not consider education to be useful, $\beta=0$, the corner solution foresees only private consumption. The optimal tax rate is $\tau^{*}=1-\alpha$, and from equation (8B, in appendix $B$ ) the same minimum optimal rate of growth as in equation (5) is obtained.

In general, the following proposition holds:

Proposition 2: When the optimal investment in education is decided by a benevolent government and financed by general taxation, the steady state growth rate is an increasing function of households' preferences for education through the optimal tax rate: $g^{*}=g\left[\tau^{*}(\beta)\right]$.

There are substantially two channels through which public expenditure on education influences the rate of growth: (i) it increases the productivity of physical capital, and (ii) it modifies the saving decisions of households. If we consider public expenditure on education in the household utility function, then such expenditure partially substitutes for private consumption, freeing resources to increase saving and investment.

3.2 By equalizing $V(x)=V(\tau)$ (equation (9A) in appendix A and equation (10B) in appendix $B$ ), the relation between the optimal tax rate $\tau^{*}$ and the optimal ratio between investments in education and physical capital $\mathrm{x}^{*}$ can be determined:

(11) $\quad x^{*}=\tau^{\frac{1}{\alpha}} \quad$ or: $\tau^{*}=x^{\alpha}$

It is easy to verify that, for these values of $\tau^{*}$ and $x^{*}$, the growth rates $\mathrm{g}\left(\mathrm{x}^{*}\right)$ and $\mathrm{g}\left(\tau^{*}\right)$ are equal.

\section{Proposition 3:}

There exists an optimal tax rate $\tau^{*}$ which makes the rate of growth in the case of public financing of education equal to the rate of growth in the case of private investment in education. 
Are, then, both private and public investments in education perfectly equivalent? The answer is 'no'. The next section explains the differences between private and public financing of education.

\section{$4 \quad$ Investment in education and change in consumer preferences}

4.1. To understand the differences between public and private financing of education, imagine a hypothetical process of economic development in three phases.

Phase 1. A neoclassical growth model with physical capital only.

At time $\mathrm{t}=0$, each household possesses a stock of capital $\mathrm{k}_{0}>0$ and a basic level of education (e.g. compulsory schooling) normalized to $1: \mathrm{h}_{0}=1$. In the household's utility function the value assigned to $\mathrm{h}_{0}$ is $\beta_{0}=0$. In fact, education can be considered a superior good, so that below a minimum level of income $\mathrm{y}^{\circ}$ the optimal choice is a corner solution with nil expenditure on education. All income is devoted to consumption and investment in physical capital. Given this Ramsey's framework, the solution of the optimum problem of the representative household yields the following steady-state equilibrium:

$$
\boldsymbol{E}_{0}^{*}:\left\{k_{0}^{*}=\left(\frac{\alpha}{\rho}\right)^{\frac{1}{1-\alpha}}, \quad y_{0}^{*}=\left(k_{0}^{*}\right)^{\alpha}, \quad g_{0}^{*}=0\right\}
$$

If $\mathrm{k}_{0} *>\mathrm{k}_{0}$ there will be a phase of transition during which the economy grows at a decreasing rate until it reaches the steady state equilibrium $E_{0} *$. However, households may have differing abilities to utilize their capital stock, so that the steady-state equilibrium will be more rapidly approached. Thus each agent will be at a different point on the path leading from $\mathrm{y}_{0}$ to $\mathrm{y}_{0} *$, and the distribution of individual incomes can be described by the equation: $y_{t+1}^{i}=y_{t}^{i}+\lambda^{i}\left(y_{0}^{*}-y_{t}^{i}\right)$, for $\mathrm{i}=0, \ldots, 1$.

Phase 2. Change in preferences. A growth model with physical and human capital .

Suppose that at time $\mathrm{t}=\mathrm{t}_{1} \mathrm{n}_{1}(<1)$ households exceed the threshold value $\mathrm{y}^{\circ}$ of per capita income and then change their preferences regarding education from $\beta_{0}=0$ to $\beta_{1}>0$. There will now arise in society a class of households which decide to spend a share of their income on education for themselves or for their children. Then $\mathrm{n}_{1}$ individuals achieve an intermediate level of education (e.g. secondary school): $\mathrm{h}_{1}>\mathrm{h}_{0}=1$. The optimal choice problem faced by these $\mathrm{n}_{1}$ 
individuals is described by the model in Section 2. The steady-state equilibrium $E_{1} *$ is the following (see equation ( $8 A$ ) in appendix $A$ ) :

$$
\boldsymbol{E}_{1} *: \quad\left\{x\left(\beta_{1}\right)>x\left(\beta_{0}\right)=0, \quad g_{1}\left(t>t_{1}\right)=\frac{1}{\sigma}\left[\alpha x\left(\beta_{1}\right)^{1-\alpha}-\rho\right], \quad y_{1}\left(t>t_{1}\right)=y\left(t_{1}\right) e^{g_{1}\left(t-t_{1}\right)}\right\}
$$

For the economy as a whole, the steady-state equilibrium is given by the weighted average of agents with a basic education $\mathrm{h}_{0}$, in number $\left(1-\mathrm{n}_{1}\right)$, and of agents with an intermediate education $\mathrm{h}_{1}$, in number $\mathrm{n}_{1}$ :

$$
\begin{aligned}
& y\left(t>t_{1}\right)=n_{1} y_{1}(t)+\left(1-n_{1}\right) y_{0} \\
& g\left(t>t_{1}\right)=n_{1} g_{1}+\left(1-n_{1}\right) g_{0}=n_{1} g_{1} \\
& h\left(t>t_{1}\right)=n_{1} h_{1}+\left(1-n_{1}\right) h_{0}=1+n_{1}\left(h_{1}-1\right)
\end{aligned}
$$

Because higher-educated agents earn an income $\mathrm{y}_{1}(\mathrm{t})$ greater than that of lower-educated agents, suppose that their number increases according to the following rule:

$$
n_{1}\left(g_{1}, t\right)=1-\frac{y_{0}}{y_{1}(t)}=1-e^{-g_{1}\left(t-t_{1}\right)}
$$

where $g_{1}$ is the rate of growth corresponding to $\beta_{1}$.

As a consequence, the economy's growth rate and the level of per capita income become:

$$
\begin{array}{ll}
g(t)=n_{1}\left(g_{1}, t\right) \cdot g_{1} & \text { for } \mathrm{t}>\mathrm{t}_{1} \\
y(t)=\left(1-n_{1}(t)\right) y_{0}+n_{1}(t) y\left(t_{1}\right) e^{g_{1}\left(t-t_{1}\right)} &
\end{array}
$$

As time passes, $n_{l}(t) \rightarrow 1$ : that is to say, practically the entire population will acquire an intermediate level of education $h_{1}>1$, and income disparities will diminish. This higher average level of education improves the overall efficiency of the economy, but it transforms education into a positive externality whereby no agent is able to obtain an income differential which off-sets the investment made.

Phase 3. The limit to growth entailed by investment in education.

Suppose that at time $\mathrm{t}=\mathrm{t}_{2} \mathrm{n}_{2}(<1)$ households $($ e.g. those that have been the first to achieve a higher level of income ) will switch their preferences to a higher level of education: $\beta_{2}>\beta_{1}>\beta_{0}=0$. They will devote a greater share of their income to education so that they can attain a higher schooling level (university education) : $h_{2}>h_{1}>h_{0}=1$. Given that $\mathrm{x}(\beta)$ is an increasing function of $\beta^{12}$, the new growth rate $\mathrm{g}\left(\beta_{2}\right)$ will be higher than the previous one, $g\left(\beta_{1}\right)$. The greater the per capita

\footnotetext{
${ }^{12}$ As long as the ratio between investment in education and physical capital $x(\beta)$ is less than maximum value $x_{M}$ : see Appendix A.
} 
income $\mathrm{y}_{2}$ of the higher-educated population, the more rapid will be the increase in the share of the population which invests in education. Income differentials will reduce and higher education, too, will become a positive externality which improves the economy's overall productivity.

However, this cumulative evolution of household preferences driven by income differentials will encounter a limit. As shown in the Appendix A, when $\mathrm{x}(\mathrm{t})$ exceeds $\mathrm{x}_{\mathrm{M}}$, further investments in education reverse the tendency, so that the economy grows at a lower steady state rate.

Figure 2: Evolution of preferences for education $\beta$ and growth rate $g(t)$

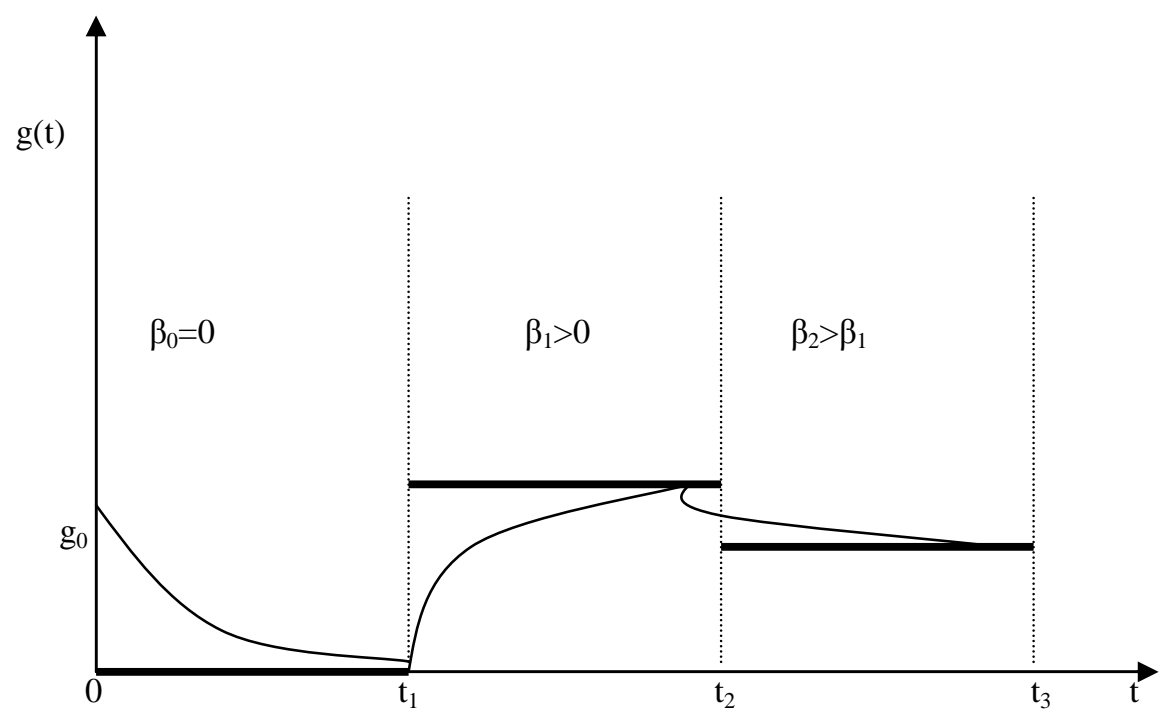

4.2. What happens when education is financed by the government? The neoclassical phase 1 is like the one just described. There will be convergence to the steady state equilibrium $\mathrm{E}_{0}{ }^{*}$, with an exogenous nil rate of growth. Households spend their net income on consumption and investment in physical capital. As soon as per capita income has sufficiently increased, the government supplies to (historically 'imposes' on) all citizens an education level $h_{1}>h_{0}=1$ financed by a proportional income tax rate. In this case the positive externality due to universalistic compulsory education will have a very strong impact on the entire population (i.e. it will be equivalent to setting $\mathrm{n}_{1}=1$ ). The generalized level of education does not increase income differentials to an extent sufficient to persuade some agents to shift their preferences to education $\beta>0$. The only effect is an increase in labour and capital productivity. If individual preferences for education $\beta$ do not change, the there will be no willingness to pay more taxes to finance a higher level of education. ${ }^{13}$ Therefore the value of $\beta$ at which agents' preferences stabilize will be lower than the value of $\beta$ which could be obtained were it driven by per capita income differentials. Given that the rate of growth is an increasing function of the optimal tax rate $\tau^{*}(\beta)$ (see Appendix $B$ ), it may happen that the public 
financing of education is insufficient to sustain an optimal rate of growth owing to education's nature as a positive externality.

\section{Conclusions}

The paper has examined the possibilities and limits of a growth process driven by investment in schooling, health and culture: in short, education. It is well known that this investment promotes economic growth not only by increasing labour productivity, but also by shifting household preferences to education. As a consequence, expenditure on education partly substitutes for consumption, thus freeing resources for the accumulation of physical capital. This cumulative process is bounded, and its limit is determined by the productive technology, specifically by the substitutability between physical and human capital. Thereafter, further investments in education slow down growth rather that accelerate it.

The differences between a growth process guided by a benevolent government and one driven by individual choices have been highlighted. A process led by the government would be more efficacious in the first phase of economic take-off because the extension of education to the entire population would produce a strong positive externality on labour productivity. In subsequent phases, a process driven by individual choices would be more long-lasting, and it would establish the optimal ratio between human and physical capital through a change in household preferences driven by income differentials.

Briefly, in the initial phase of an economy's take-off, public intervention on behalf of all citizens is preferable. Thereafter, I believe it advisable to leave individuals free to make their own decisions on investment in education.

\footnotetext{
${ }^{13}$ Note that the optimal tax rate $\tau^{*}$ is an increasing function of $\beta$, see Appendix B.
} 
Appendix A : The steady state growth rate $g *$ with private financing of education.

The solution of the optimization problem is obtained by deriving from the Hamiltonian function the following first-order maximum conditions:

$$
\begin{aligned}
& e^{-\rho t} u_{c}(t)-\mu(t)=0 \\
& e^{-\rho t} u_{h}(t)-\mu(t)+\mu(t)(1-\alpha) x(t)^{-\alpha}=0 \\
& -g_{\mu}(t)=\alpha x(t)^{1-\alpha}
\end{aligned}
$$

$$
g_{k}(t)=x(t)^{1-\alpha}-\frac{c(t)}{k(t)}-x(t)
$$

where $\rho>0$ is the intertemporal discount rate, and

$$
g_{y}(t)=\frac{y(t)}{y(t)}=\mathrm{g}(\mathrm{y}) \text { indicates the rate of growth of the variable } \mathrm{y}(\mathrm{t})
$$

Moreover, the following transversality condition must be verified: $\lim \mu(t) h(t)=0$.

Equations (1A) and (2A) define the optimal time path of the control variables $c(t)$ and $h(t)$, setting it in relation to the time path of the costate variable $\mu(t)$; equations (3A) and (4A) define the rate of variation of costate variable and capital stock respectively.

Substituting equation (1A)) in equation (2A) yields the optimal ratio between $c(t)$ and $k(t)$ :

$$
\frac{c(t)}{k(t)}=\frac{1-\beta}{\beta}\left(x(t)-(1-\alpha) x(t)^{1-\alpha}\right)>0 \quad \text { if } \quad x(t)>x_{m}=(1-\alpha)^{\frac{1}{\alpha}}
$$

The optimal growth rate of the capital stock is derived by substituting of the equation (5A) into equation (4A):

(6A) $\quad g(k)=\frac{1}{\beta}\left[(1-\alpha+\alpha \beta) x(t)^{1-\alpha}-x(t)\right]$

In steady state the ratio $x(t)$ as well as the rate of growth of the capital stock must be constant; by differentiating (4A) with respect to time, and taking account of (5A), the following steady state condition is obtained 
(7A)

$g(k)=g(h)=g(c)=g(y)=g$

The rate of growth of consumption is derived from condition (1A) (taking the logarithmic and deriving it with respect to time), taking into account of equation (3A):

(8A) $g=\frac{1}{\sigma}\left[\alpha x^{1-\alpha}-\rho\right] \quad$ or: $\quad$ (8A),$\quad x=\left(\frac{o g+\rho}{\alpha}\right)^{\frac{1}{1-\alpha}}$

On equalising equations $(6 \mathrm{~A})$ and $(8 \mathrm{~A})$, the following implicit equation is obtained:

$$
V(x)=x^{1-\alpha}[\sigma(1-\alpha+\alpha \beta)-\alpha \beta]-\sigma x+\beta \rho=0 \quad \text { where: } \frac{\partial V}{\partial x}<0^{14}
$$

The optimal constant value $x^{*}$ is obtained by solving equation (9A); by substituting $x *$ in equation (8A), we obtain the steady state growth rate of income:

(10A) $g^{*}=\frac{1}{\sigma}\left[\alpha\left(x^{*}\right)^{1-\alpha}-\rho\right]$

where $\mathrm{g}^{*}$ is an increasing function of $\mathrm{x}^{*}$.

We define the relation between $\mathrm{x}$ and the preference for education $\beta$ from implicit equation (9A):

$$
\operatorname{sign} \frac{\partial x(\beta)}{\partial \beta}=\operatorname{sign} \frac{\partial V}{\partial \beta}=\frac{\rho R-x}{\sigma R-\beta}><0^{15} \quad \text { for: } x<>x_{M}=\rho R \quad \text { where: } R=\frac{1-\alpha}{\alpha(1-\sigma)}
$$

Finally, the limit condition is satisfied if $: h_{0}<\left(\frac{\rho}{\alpha(1-\sigma)}\right)^{\frac{1}{1-\alpha}} k_{0}$

A different way to present the same result consists in substituting equation (8A)' in equation (6A), obtaining an implicit equation in $\mathrm{g}^{*}$ as function of deep parameters $(\sigma, \rho, \alpha)$ and the preferences for education $\beta$ : see equation (4) in the text.

${ }^{14}$ In fact, we have: $x \frac{\partial V}{\partial x}=(1-\alpha) x^{1-\alpha}[\sigma(1-\alpha+\alpha \beta)-\alpha \beta]-\sigma x=-\alpha \sigma x-(1-\alpha) \beta \rho<0$ for every value of root $\mathrm{x}$ of equation $\mathrm{V}(\mathrm{x})=0$.

${ }^{15}$ In fact, $(\sigma \mathrm{R}-\beta)>0$ in the entire interval $0 \leq \beta \leq 1$ provided that $\sigma \geq \alpha$; in any case this is the most reasonable hypothesis on the relation between the parameters. 
Appendix B : Proof of existence of the steady state equilibrium growth rate $g^{*}$ with public financing of education.

I introduce the first-order maximum conditions obtained by deriving the Hamiltonian function with respect to the control variable $c(t)$ and $\tau(\mathrm{t})$ and the state variable $k(t)$ :

$$
g_{k}(t)=-\frac{c(t)}{k(t)}+(1-\tau) A(\tau)
$$

Equations (1B) and (2B) define the optimal time path of the control variables $c(t)$ and $\tau(t)$, setting it in relation to the time path of the costate variable $\mu(t)$; equations (3B) and (4B) define the rate of variation of costate variable and capital stock respectively.

Note that in steady state the rate of growth of the capital stock must be constant; therefore, by differentiating (4B) with respect to time, it must be: $g_{c}(t)=g_{k}(t)=\mathrm{g}_{\mathrm{y}}(\mathrm{t})=\mathrm{g}$.

Substituting equation (1B) in (2B) and (3B) yields the rate of growth of the costate variable and the optimal ratio between consumption and capital:

$$
-g_{\mu}(t)=\frac{\beta}{1-\beta} \frac{c(t)}{k(t)}+(1-\tau) A(\tau)
$$

(6B) $\frac{c(\tau)}{k(\tau)}=\frac{1-\beta}{\beta}(\tau+\alpha-1) A(\tau)>0 \quad$ for $\tau>\tau_{\mathrm{m}}=1-\alpha^{16}$

Then, given the optimal ratio between consumption and capital, the rate of growth of the costate variable is defined:

$$
-g_{\mu}(t)=\alpha A(\tau)
$$

\footnotetext{
${ }^{16}$ Note that in order to have positive private consumption $\mathrm{c}(\mathrm{t}) / \mathrm{k}(\mathrm{t})$, this constraint must be satisfied.
} 
I take the logarithmic of the condition (1B) and derive it with respect to time. Taking account of the above equality between rates of growth, and equation (7B), the rate of growth of consumption is derived as:

(8B) $\quad g(c)=g=\frac{1}{\sigma}[\alpha A(\tau)-\rho] \quad$ or: $\quad(8 \mathrm{~B}), \quad \tau=\left(\frac{\sigma g+\rho}{\alpha}\right)^{\frac{\alpha}{1-\alpha}}$

The optimal growth rate of the capital stock can be obtained by substituting equation (6B) in equation (4B), :

(9B) $\quad g(k)=g=\frac{A(\tau)}{\beta}[(1-\alpha+\alpha \beta)-\tau]$

Finally, by equalising equations (8B) and (9B), we obtain the following implicit relation which defines the optimal income tax rate:

(10B) $V(\tau)=\alpha A(\tau)[B(\beta)-\beta]-\sigma \tau A(\tau)+\beta \rho=0 ; \quad \frac{\partial V(\tau)}{\partial \tau}<0^{17}$

Note that $\mathrm{V}(\tau)$ is a concave function of $\tau$ which decreases for $\tau>\tau_{\mathrm{m}}$. There will be an optimal $\tau^{*}$ such the $\mathrm{V}\left(\tau^{*}\right)=0$. Moreover, it is easy to ascertain from (8B) that $\mathrm{g}$ is an increasing function of $\tau$. We can define the relation between the optimal tax rate and the preferences for education $\beta$ from implicit equation (10B):

$$
\operatorname{sign} \frac{\partial \tau(\beta)}{\partial \beta}=\operatorname{sign} \frac{\partial Z}{\partial \beta}=-\alpha(1-\sigma) A(\tau)+\rho><0 \quad \text { for: } \tau<>\tau_{M}=\left(\frac{\rho}{\alpha(1-\sigma)}\right)^{\frac{\alpha}{1-\alpha}}
$$

A different way to present the same result consists in substituting equation (8B)' in equation (9B), obtaining an implicit equation in $g$ as function of deep parameters $(\sigma, \rho, \alpha)$ and the preferences for education $\beta$ : see equation (9) in the text.

${ }^{17}$ In fact: $\quad \operatorname{sign} \frac{\partial V(\tau)}{\partial \tau}=\operatorname{sign}[\alpha(1-\alpha)(1-\sigma)(\sigma R-\beta)-\sigma \tau]<0 \quad$ for $\tau \geq \tau_{\mathrm{m}}=(1-\alpha)$ 
References

Aghion P. , Howit P. (1992), A Model of Growth through Creative Destruction, "Econometrica", 60 , pp.323-351

Alesina A., Rodrik D. (1994), “Distributive Policies and Economic Growth”, Quarterly Journal of Economics, 109:2, 465-9

Bajo-Rubio O. (2000), A further Generalization of the Solow Growth Model: the Role of the Public Sector, "Economic Letters", 68, pp.79-84

Barro R.J. (1990), Government Spending in a Simple Model of Endogenous Growth, "Journal of Political Economy", 98, pp.103-125

Barro R.J., Sala-I-Martin X. (1992), Public Finance in Models of Economic Growth, "Review of Economic Studies", 59, 4, pp.645-661

Barro R.J., Sala-I-Martin X. (1995), Economic Growth, McGraw-Hill, N.Y.

Barro R.J. (1996), Health and Economic Growth. Paper prepared for the Pan American Health Organization.

Becker, G.S. (1993), Human capital- A Theoretical and Empirical Analysis with Special Reference to education, University of Chicago Press

Benabou R. (1994), Human capital, inequality and growth: the local perspective, European Economic Review 38, pp.817-826

Card D. (1999), The causal effect of Education on Earnings, in O. Ashenfelter and D.Card, eds., Handbook of Labor Economics, 3, 1801-1863

Bloom, D.E, Canning, D., Sevilla, J. (2001), The Effect of Health on Economic Growth: Theory and Evidence, NBER Working Paper n.8587

De la Croix and Doepke M. (2004), Public versus Private Education when differential fertility matters, Journal of Development Economics, 93, pp.1091-113

Epple D., Romano R., (1998), Competition between private and public schools, vouchers, and peergroup effect, American Economic Review, 88, pp.33-62

Erickson, C.L. and Ichino, A. (1992), Wage differential in Italy: Market forces, Institutions, and Inflation, in R.Freeman and L.Katz (eds), Difference and Changes in the wage Structure, NBERUniversity of Chicago Press.

Flessig A.R., Rossana R.J. (2003), Are Consumption and Government Expenditures Substitutes or Complements? Morishima Elasticity Estimates from the Fourier Flexible Form, Economic Inquiry, January, 41,1, pp.132-146.

Futagami, K., Y. Morita and S. Akihisa. (1993) 'Dynamic analysis of an endogenous growth model with public capital,' Scandinavian Journal of Economics, 95, pp.607-25 
Galor O., Tsidon D., (1997), The distribution of human capital and economic growth, Journal of Economic Growth, 2, pp.93-124

Galor O. and Mayer D. (2002), Food for Thougth: Basic needs and persistent educational inequality. Paper prepared for the Pan American Health Organization, Washington, October 4

Glomm G. and Ravikumar B. (1992), Public versus private investment in human capital:

Endogenous growth and income inequality, Journal of Political Economy, 100, 4, pp.818-834

Gradstein M., Justman M., (1997), Democratic Choiche of an education system: Implication for Growth and Income Distribution, Journal of Economic Growth, 2, pp.169-183

Greiner, A., Hanusch, H. (1998). Growth and welfare effects of fiscal policy in an endogenous growth model with public investment. International Tax and Public Finance, 5(3), pp.249-261.

Griliches, Z. (1977), Estimating the Returns to Schooling: Some Econometric Problems, Econometrica, 45,1, pp.1-22

Harmon, C. , Walker I. (1995), Estimates of the Economic Return to Schooling for the United Kingdom, American Economic Review, 85, pp.1278-1286

Hosoya K. (2003), Tax financed government health expenditure and growth with capital deepening externality, Economic Bulletin, 5,14, pp.1-10

Howitt P. (2002), Health, human capital and economic growth: a Schumpeterian perspective. in: Lopez.Casasnovas G., Rivera B., Currais L. (editors), Health and Economic growth. Findings and Policy Implications, The MIT Press, Cambridge, Mass.

Ichino A., Winter-Ebmer R. (1998), Lover and Upper Bound of Returns to Schooling: an exercise in IV estimation with different instruments, European Economic Review, pp. ...

Jones L.E. , Manueli R.E. (1990), A convex model of equilibrium growth: theory and policy implications, Journal of Political Economy, 88, pp.1008-1038

Lucas R. (1988), On the Mechanics of Economic Development, in "Journal of Monetary Economics", 22, pp.3-42

Lucifora C. (1994), Determinazione del salario in Italia: una rassegna della letteratura empirica. Il contributo dell'analisi con microdati, in C.Dell'Aringa (ed), La determinazione del salari, Napoli, Edizioni Scientifiche Italiane

Manacorda, M. (2000), The Evolution of Return sto Education in Italy, 1978-1992: Changin Institutions or Changing Supply and Demand? In R.B.Freeman (ed), Inequality Around the World, Macmillan \& St.Martin's Press

Miguel E. (2005), Health, Education, and Economic Development, in Lopez.Casasnovas G., Rivera B., Currais L. (editors), Health and Economic growth. Findings and Policy Implications, The MIT Press, Cambridge, Mass.

Mincer, J (1974), Schooling, Experience, and Earnings, New York, NBER 
Peretto P.F. (2003), Fiscal Policy and Long-run Growth in R\&D-based Models with Endogenous Market Structure, "Journal of Economic Growth", 8, 325-347

Psacharopoulos, G. (1994), Retirns to Investment in education: a global Update, World Development, 22, 9, pp.1325-1343

Rebelo S.T. (1991), Long-Run Policy Analysis and Long-Run Growth”, "Journal of Political Economy", 99,pp.500-521.

Romer P.M. (1986), Increasing Returns and Long-Run Growth, "Journal of Political Economy", 94, pp.1002-1037

Romer P.M. (1990), Endogenous Technological Change, “Journal of Political Economy", 98, pp.71-101

Romer P.M. (1994), The Origins of Endogenous Growth, "Journal of Economy Perspective", 8, pp.3-22

Sala-i-Martin X. (2005), On the Health-Poverty Trap, in Lopez.Casasnovas G., Rivera B., Currais L. (editors), Health and Economic growth. Findings and Policy Implications, The MIT Press, Cambridge, Mass.

Scott M.F. (1992), Policy Implications of 'a New View of Economic Growth', "Economic Journal",102, pp.622-632;

Shaw K.G. (1992), Policy Implications of Endogenous Growth Theory, "Economic Journal”,102, pp.611-621.

Solow R. (1956), A Contribution to the Theory of Economic Growth, "Quarterly Journal of Economics, 70, pp.65-94

Turnovsky, S.J., (1996), Optimal Tax, Debt and Expenditure Policies in a Growing Economy, Journal of Public Economics, 60, pp.21-44

Turnovsky, S.J., (2000), Fiscal Policy, Elastic Labour Supply, and Endogenous Growth, Journal of Monetary Economics, 45, pp.185-210

Van Zon A., Muyshen J. (2001), Health and Endogenous growth. Journal of health Economics, 20, pp.169-185

Willis, R.J. and Rosen S. (1979), Education and Self-selection, Journal of Political Economy, 87, 5, pp.S7-S36

Willis, R.J. (1986), Wage Determinants: A Survey and reinterpretation of Human Capital Earnings Function, in Ashenfelter O. and Layard R., Handbook of Labor Economics, Amsterdam: North Holland.

Zagler, M., Durneker, G., (2003), Fiscal Policy and Economic Growth, Journal of Economic Surveys, 17,3, pp.397-418 